\title{
MODEL FOR ASSESSMENT OF THE COMPETENCE OF PRODUCTION MANAGERS
}

\author{
Krasimira Dimitrova ${ }^{1}$ \\ Tanya Panayotova ${ }^{2}$ \\ Neli Veleva ${ }^{3}$
}

DOI: https://doi.org/10.31410/LIMEN.2020.245

\begin{abstract}
This publication presents an experimental model for assessing the competence of production managers, which is based on classical management and modern mathematical tools. The research was done in response to a real practical need set as a research task by the business. As a result, a model for selection of specialists and experts for solving complex management problems related to production management in industrial enterprises and an algorithm for application of this model is proposed. Key indicators for assessing the competence of production managers have been identified. To create the model, surveys conducted among functional experts in the field of production management were used. The model can be successfully applied in other functional areas of management, modifying the key indicators so that they are applicable in these areas.
\end{abstract}

Keywords: Competency assessment, Competency assessment model, System of indicators, Main indicators, Secondary indicators, Delphi method.

\section{INTRODUCTION}

$\mathrm{T}$ The present study is provoked by a specific need in production management, related to the analysis and planning of production capacity in industrial enterprises and the solution of complex problems and crisis situations. In the course of the research some summaries and conclusions were made regarding the universal applicability of the obtained results.

Production capacity is a key complex economic parameter of the enterprise and its effective planning and management is the basis of success and competitiveness of any production organization. This raises the need to put on a scientific basis the selection of specialists who will make important management decisions.

The study aims to develop a model for determining the competence of a team of specialists to make management decisions related to the identification, analysis and evaluation of key factors influencing the capacity of industrial enterprises. The model treats the selection and assessment of the competence of experts in forming teams to solve specific production problems related to the management of the production capacity of enterprises. The model provides the definition, selection and ranking of factors influencing the interaction and relationships between them, as

Technical University of Varna, Faculty of Management, Studentska str. 1, Varna, Bulgaria Technical University of Varna, Faculty of Management, Studentska str. 1, Varna, Bulgaria Technical University of Varna, Faculty of Management, Studentska str. 1, Varna, Bulgaria
Mechanical Engineering, Department of Industrial

Mechanical Engineering, Department of Industrial

Mechanical Engineering, Department of Industrial 
well as their influence and role in decision-making related to the management of production capacity.

Various indicators, tools and methods are analyzed to identify trends, problems and challenges in the formation of expert teams. Current data and various methods for analysis of the generated information are used.

\section{RESEARCH RESULTS}

Based on an in-depth literature review and personal interviews with various functional managers from industrial enterprises, the need to determine an index of competence of experts in the field of production management has been established. In order to obtain real and objective results of the study, 15 experts from 10 production and research organizations were involved to propose criteria for evaluation of experts who must form a team to solve complex problems in the field of production management.

The study was conducted in three stages. The Delphi method, widely used in management, is applied as a method for making decisions based on a certain amount of information collected and analyzed (Rao J., Anderson L., Sukumar B., Beauchesne D., Stein T., Frankel R. (2010), pp. 5-7). Geng Y, Zhao L, Wang Y, Jiang Y, Meng, K, Zheng D (2018) used Delphi method to construct a competency model for dentists in China. Their idea is used in this study, but it is adopted and applied for the purpose of forming an expert team for decision making in the field of Production management. (pp. 9-11)

Figure 1. Flowchart of the study

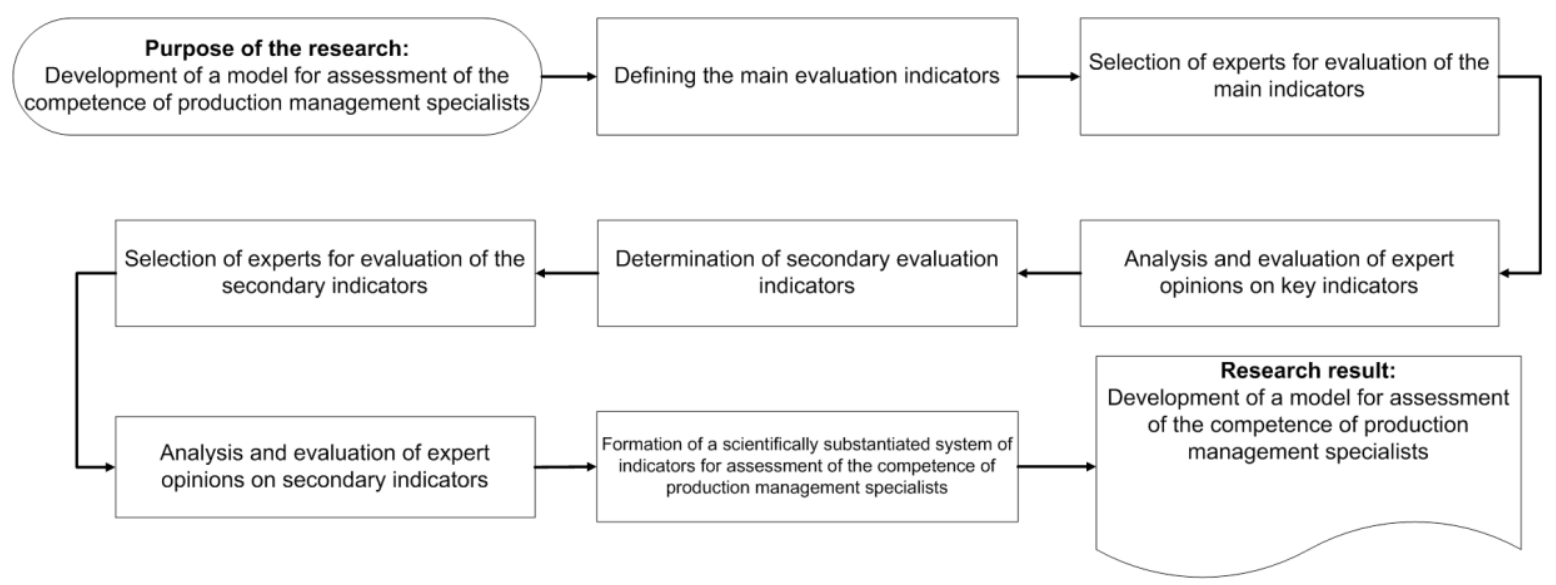

Stage 1. Determination of the primary indicators for assessment of the competence of the specialists, which should be included in the team for solving production problems.

The received expert opinions from the respondents are processed and systematized. At the first level, nine primary indicators are defined:

1. Professional skills,

2. Prevention of production risks,

3. Management skills and skills for collecting and processing information,

4. Professional knowledge and ability to learn throughout life,

5. Interpersonal communication skills,

6. Team work skills, 
7. Research opportunities,

8. Basic values of managers.

9. Professionalism of managers.

The defined primary indicators are decomposed into secondary ones, which will guarantee objectivity in the assessment and selection of the specialists in the future team. Secondary indicators are the further development of primary indicators. The aim is to select the really important criteria and indicators for assessing the competence of the experts who will be selected to solve important management tasks and problems. The indicators have been adjusted and supplemented according to the comments of the experts participating in the study. A different number of secondary indicators are defined for each main indicator (Table 1).

Table 1. System of indicators - main and secondary indicators for assessment of the competence of experts in the field of production management

\begin{tabular}{|c|c|c|}
\hline Basic indicators & & Secondary indicators \\
\hline \multirow{19}{*}{ 1. Professional skills } & 1.1 & Knowledge of management theory. \\
\hline & 1.2 & $\begin{array}{l}\text { Knowledge and experience in applying theoretical management } \\
\text { methods in practice. }\end{array}$ \\
\hline & 1.3 & Ability to properly select appropriate process monitoring tools. \\
\hline & 1.4 & $\begin{array}{l}\text { Ability to report to a senior manager on standard production problems } \\
\text { encountered and ability to analyze and explain problems. }\end{array}$ \\
\hline & 1.5 & Ability to make management decisions based on facts. \\
\hline & 1.6 & Ability to identify potential risks. \\
\hline & 1.7 & $\begin{array}{l}\text { Independence and objectivity in making decisions related to direct } \\
\text { responsibilities. }\end{array}$ \\
\hline & 1.8 & Ability for multidisciplinary comprehensive analysis. \\
\hline & 1.9 & Ability to combine theoretical knowledge with production practice. \\
\hline & 1.10 & Proper use of production equipment and resources. \\
\hline & 1.11 & Ability to standardize basic operations. \\
\hline & 1.12 & Ability to handle heavy loads. \\
\hline & 1.13 & $\begin{array}{l}\text { Ability to perform independent analysis in special circumstances } \\
\text { (difficult cases). }\end{array}$ \\
\hline & 1.14 & Possession of skills and knowledge of basic technologies. \\
\hline & 1.15 & $\begin{array}{l}\text { Ability to predict the results of its decisions, risks, benefits and the } \\
\text { expected effect of various actions aimed at a specific goal. }\end{array}$ \\
\hline & 1.16 & $\begin{array}{l}\text { Skills in using professional terminology, developing and discussing } \\
\text { production plans, cost estimates, time requirements and responsibilities. }\end{array}$ \\
\hline & 1.17 & Ability to deal with crisis situations. \\
\hline & 1.18 & $\begin{array}{l}\text { Using management methods and techniques to deal with current } \\
\text { problems and their consequences. }\end{array}$ \\
\hline & 1.19 & $\begin{array}{l}\text { Ability to identify the psychological and social factors of the work } \\
\text { environment and the ability to properly deal with the adverse effects of } \\
\text { psychological and behavioral factors. }\end{array}$ \\
\hline \multirow{3}{*}{$\begin{array}{l}\text { 2. Prevention of } \\
\text { production risks }\end{array}$} & 2.1 & $\begin{array}{l}\text { Identification and timely response and reporting of problematic } \\
\text { situations }\end{array}$ \\
\hline & 2.2 & Ability to take preventive action. \\
\hline & 2.3 & $\begin{array}{l}\text { Understanding of their responsibilities and ability to cooperate with } \\
\text { other functional areas of management. }\end{array}$ \\
\hline
\end{tabular}




\begin{tabular}{|c|c|c|}
\hline & 2.4 & Understanding the structure and function of the management system. \\
\hline & 2.5 & Rational use of resources. \\
\hline & 2.6 & Ability to actively participate in educational and training programs. \\
\hline & 2.7 & $\begin{array}{l}\text { Abilities for planning and implementation of maintenance of } \\
\text { production equipment. }\end{array}$ \\
\hline & 2.8 & $\begin{array}{l}\text { Objective assessment of the short-term and long-term effects of the } \\
\text { policy and strategy of the production organization. }\end{array}$ \\
\hline & 2.9 & Ability to assess risk factors. \\
\hline \multirow{10}{*}{$\begin{array}{l}\text { 3. Management } \\
\text { skills and skills for } \\
\text { collecting and } \\
\text { processing } \\
\text { information }\end{array}$} & 3.1 & $\begin{array}{l}\text { Use of various databases and other means to extract, collect and analyze } \\
\text { information. }\end{array}$ \\
\hline & 3.2 & $\begin{array}{l}\text { Effective use of information technology for communication with } \\
\text { managers, employees. }\end{array}$ \\
\hline & 3.3 & Ability to control production costs. \\
\hline & 3.4 & $\begin{array}{l}\text { Effective organization of own work and good planning of work of } \\
\text { production units. }\end{array}$ \\
\hline & 3.5 & Skills to self-manage and deal wisely with their own activities. \\
\hline & 3.6 & $\begin{array}{l}\text { Continuous improvement of organizational coherence and leadership in } \\
\text { practice }\end{array}$ \\
\hline & 3.7 & Possession of certain professional skills in a foreign language. \\
\hline & 3.8 & $\begin{array}{l}\text { Skills to create and use accurate, consistent and clear production } \\
\text { management documentation. }\end{array}$ \\
\hline & 3.9 & Reasonable and efficient management of the production process. \\
\hline & 3.10 & Skills to use modern information technologies. \\
\hline \multirow{5}{*}{$\begin{array}{l}\text { 4. Professional } \\
\text { knowledge and } \\
\text { ability to learn } \\
\text { throughout life }\end{array}$} & 4.1 & Basic knowledge in other functional areas as well. \\
\hline & 4.2 & $\begin{array}{l}\text { Knowledge of behavioral and social sciences, professional ethics and } \\
\text { laws. }\end{array}$ \\
\hline & 4.3 & Knowledge and application of basic professional knowledge. \\
\hline & 4.4 & Constant updating of knowledge and professional skills \\
\hline & 4.5 & Active participation in continuing education. \\
\hline \multirow{11}{*}{$\begin{array}{l}\text { 5. Interpersonal } \\
\text { communication } \\
\text { skills }\end{array}$} & 5.1 & $\begin{array}{l}\text { Careful collection of information related to the analysis and synthesis } \\
\text { of various problems. }\end{array}$ \\
\hline & 5.2 & Understanding, trust and respect for colleagues and their families. \\
\hline & 5.3 & Protection and observance of confidentiality. \\
\hline & 5.4 & Ability to work with confidential information. \\
\hline & 5.5 & Dealing with ethical issues that arise in the process of work. \\
\hline & 5.6 & Conflict management skills. \\
\hline & 5.7 & Active conflict prevention and resolution. \\
\hline & 5.8 & Ability to create a friendly work environment. \\
\hline & 5.9 & Creating safe working conditions. \\
\hline & 5.10 & $\begin{array}{l}\text { Opportunities for effective communication, transmission of } \\
\text { information when assigning tasks. }\end{array}$ \\
\hline & 5.11 & $\begin{array}{l}\text { Opportunities for effective communication with representatives of } \\
\text { external organizations and other stakeholders. }\end{array}$ \\
\hline \multirow{7}{*}{ 6. Team work skills } & 6.1 & $\begin{array}{l}\text { Skills to work with colleagues and respect their abilities and } \\
\text { contribution. }\end{array}$ \\
\hline & 6.2 & Skills to develop action plans. \\
\hline & 6.3 & Care for colleagues willing to help colleagues. \\
\hline & 6.4 & Understanding the roles and responsibilities of others in the team. \\
\hline & 6.5 & Good coordination with team members to avoid conflict. \\
\hline & 6.6 & Ability to establish good relations of cooperation with other teams. \\
\hline & 6.7 & Ability to train and be trained. \\
\hline
\end{tabular}




\begin{tabular}{|c|c|c|}
\hline \multirow{6}{*}{$\begin{array}{l}\text { 7. Research } \\
\text { opportunities }\end{array}$} & 7.1 & $\begin{array}{l}\text { Possessing skills for critical thinking in professional activities and } \\
\text { decision making. }\end{array}$ \\
\hline & 7.2 & $\begin{array}{l}\text { Understanding the complexity and uncertainty of activities in } \\
\text { conditions of uncertainty. }\end{array}$ \\
\hline & 7.3 & $\begin{array}{l}\text { Ability to review specific (required) literature and ability to apply and } \\
\text { share knowledge. }\end{array}$ \\
\hline & 7.4 & $\begin{array}{l}\text { Abilities for conscious development of one's own creative thinking and } \\
\text { innovations. }\end{array}$ \\
\hline & 7.5 & Active participation in research activities. \\
\hline & 7.6 & Commitment to the goals of the organization \\
\hline \multirow{7}{*}{$\begin{array}{l}\text { 8. Basic values of } \\
\text { managers }\end{array}$} & 8.1 & Protecting the interests of the organization. \\
\hline & 8.2 & Self-discipline to achieve sustainable development of the organization. \\
\hline & 8.3 & Ability to predict. \\
\hline & 8.4 & Good psychological setting. \\
\hline & 8.5 & High capacity for emergency response. \\
\hline & 8.6 & Discipline \\
\hline & 8.7 & Ability to negotiate, prove and defend a personal position. \\
\hline \multirow{7}{*}{$\begin{array}{l}\text { 9. Professionalism of } \\
\text { managers }\end{array}$} & 9.1 & Care for subordinates. \\
\hline & 9.2 & Cultivation and empathy for basic organizational values. \\
\hline & 9.3 & $\begin{array}{l}\text { Strong sense of responsibility, with a positive attitude to work and } \\
\text { professionalism. }\end{array}$ \\
\hline & 9.4 & Fair and prudent use of resources \\
\hline & 9.5 & $\begin{array}{l}\text { Awareness of health and safety at work and professional protection, to } \\
\text { actually reduce hazards at work. }\end{array}$ \\
\hline & 9.6 & Professional competence and self-assessment. \\
\hline & 9.7 & Validation of assessments and expertise. \\
\hline
\end{tabular}

Source: Geng Y, Zhao L, Wang Y, Jiang Y, Meng, K, Zheng D, 2018

Stage 2. After the systematization of the primary and secondary indicators, a system for overall assessment of their importance and severity has been developed (Table 2).

The assessment is made for all primary and secondary indicators in three aspects: importance, feasibility and sensitivity. A scale of 1 to 10 is used, with 1 being the lowest grade and 10 being the highest. The ability of the specific expert to understand problems and problematic situations is also assessed, using a scale from 1 to 5 , where 1 is the minimum grade and 5 is the maximum. The assessment of the ability of experts for objective assessment is based on four aspects: practical experience, ability for theoretical analysis, logical thinking and ability to understand the situation, ability for objective assessment and intuition. A scale of 1 to 3 is used for these scores, where 1 is the lowest score and 3 is the highest.

As a result, a scientifically based and working system of indicators is formed, so that a model for assessing the competence of production managers can be built, which will ensure the formation of objective expert opinion in decision-making related to the management of the production process in any production organization.

The model has been tested in real conditions. 
Table 2. Expert evaluation of the indicators

\begin{tabular}{|c|c|c|c|c|c|c|c|c|c|c|c|}
\hline & \multirow[b]{7}{*}{ № } & \multirow[b]{7}{*}{ : } & \multirow[b]{7}{*}{ 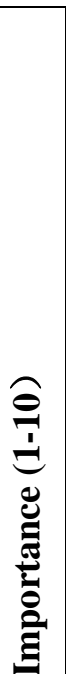 } & \multirow[b]{7}{*}{ 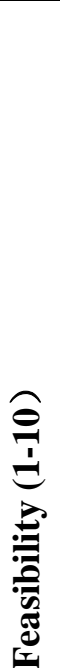 } & \multirow[b]{7}{*}{ 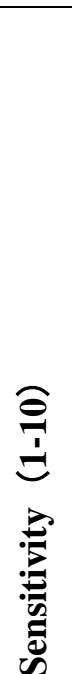 } & Familiarity: & \multirow{6}{*}{\multicolumn{5}{|c|}{$\begin{array}{l}\text { Basis of assessment and } \\
\text { degree of influence (degree } \\
\text { of influence divided into } \\
\text { three levels } \\
3 \text { = great, } \\
2 \text { = average, } \\
1 \text { = little) }\end{array}$}} \\
\hline & & & & & & 5 = very good knowledge & & & & & \\
\hline & & & & & & 4 = good knowledge & & & & & \\
\hline & & & & & & 3 = general knowledge & & & & & \\
\hline & & & & & & 2 = poor knowledge & & & & & \\
\hline & & & & & & 1 = ignorance & & & & & \\
\hline 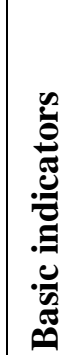 & & & & & & & 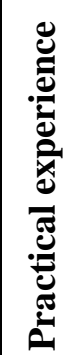 & 产 & 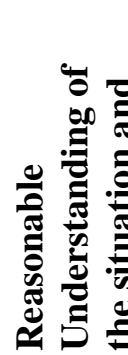 & 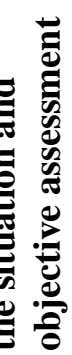 & \\
\hline
\end{tabular}

Source: Geng Y, Zhao L, Wang Y, Jiang Y, Meng, K, Zheng D, 2018

Stage 3. Creating a model for assessing the competence of each expert and an algorithm for applying the model.

Figure 2. Block diagram of model A for assessment of the competence of production managers

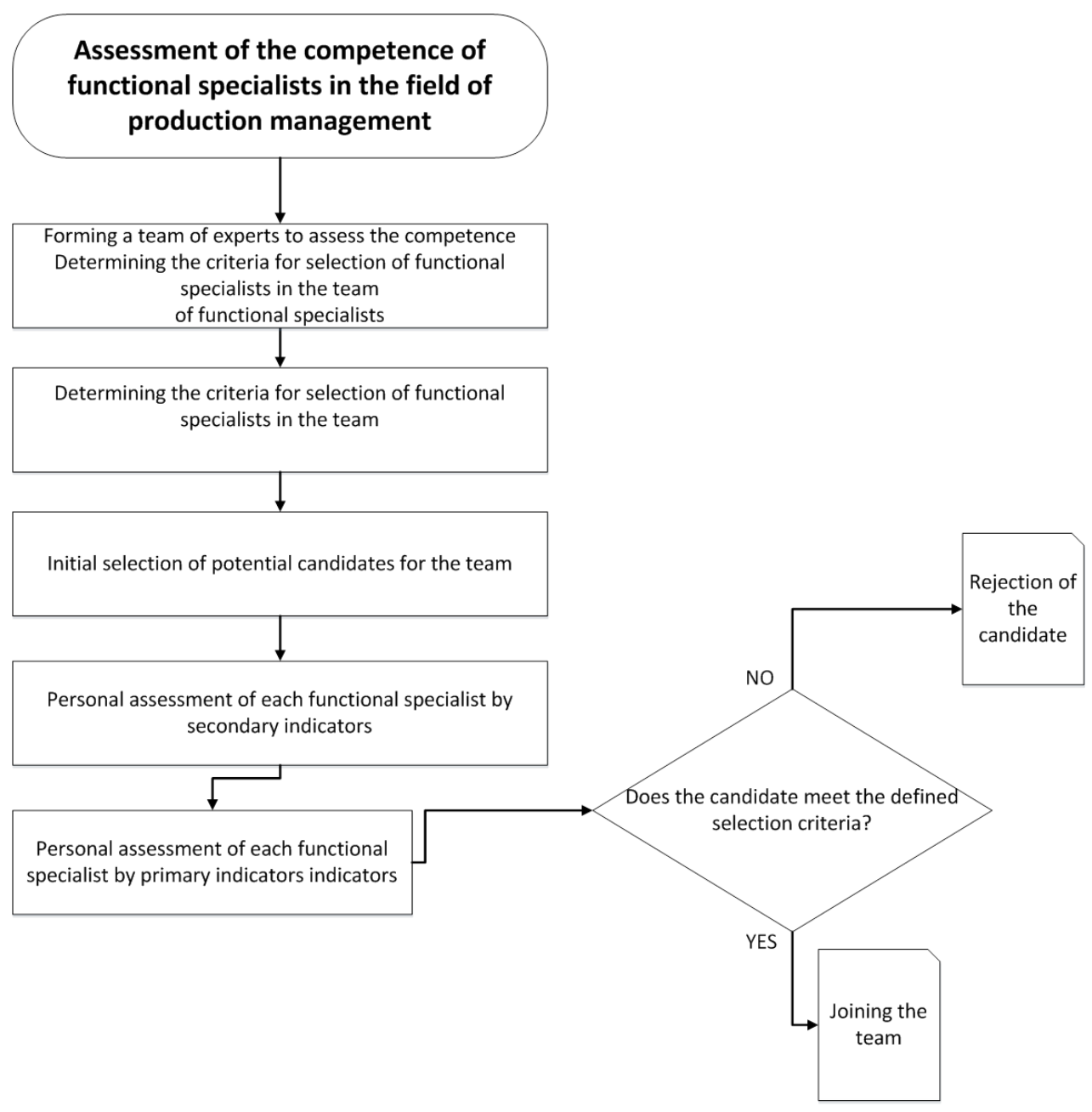




\section{FUTURE RESEARCH DIRECTIONS}

The present study is the first stage of a larger-scale research study in another research project related to the analysis and assessment of the factors influencing the effective planning and management of production capacity. It is related to the need to redefine policies and priorities in business development strategies - in particular on the planning and management of production capacity, so that industrial enterprises can successfully adapt to the dynamically changing conditions of the global environment and increasing competition. The competence of production managers is also having an increasing influence on the achievement of this goal. The project aims to expand the range of scientific results achieved in this study by developing a model for assessing the impact of various factors on the effective planning and management of production capacity.

\section{CONCLUSION}

In the current economic, financial, communication and social environment, there is the pressure on markets and consumers from the dynamic growth of business, the interdependence between resources and processes, the oversupply of uniform goods and services, the economic leadership of high-tech companies and their strategic impact on national economies and business practices. In this extremely dynamic environment, businesses must not only maintain their competitive advantages, but balance them according to societal expectations and needs, express a positive attitude to change and take concrete long-term action to adapt and withstand the challenges around them. In the ages of globalization, the need for a new model for assessing the competence of production managers is growing, which determines the relevance and importance of the research and the practical benefits it brings to business.

\section{REFERENCES}

Geng Y, Zhao L, Wang Y, Jiang Y, Meng, K, Zheng D (2018) Competency model for dentists in China: Results of a Delphi study. PLoS ONE 13 (3): e0194411. https://doi.org/10.1371/journal.pone.0194411

Rao J., Anderson L., Sukumar B., Beauchesne D., Stein T., Frankel R. (2010) Engaging communication experts in a Delphi process to identify patient behaviors that could enhance communication in medical encounters, BMC Health Services Research 10(1):97 DOI: $10.1186 / 1472-6963-10-97$

\section{ADDITIONAL READING}

Brown B. Delphi process: a methodology using for the elicitation of opinions of experts. The Rand Corporation. 1986; 9: 3925. 22. Powell C. The Delphi technique: Myths and realities. J Adv Nurs. 2004; 15): 376-382.

Grime M., Wright G., Delphi Method, (2016) DOI: 10.1002/9781118445112.stat07879

Landeta, J., Barrutia, J., and Lertxundi, A. (2011) Hybrid Delphi: a methodology to facilitate contribution from experts in professional contexts. Technol. Forecast. Soc. Change, 78, pp. $1629-1641$.

Linstone H. A., Turoff, M. (2002) The Delphi Method: Techniques and Applications, http://www.is.njit.edu/pubs/delphibook/index.html (accessed 02 February 2016).

Loo, R. (2002), "The Delphi method: a powerful tool for strategic management", Policing: An $\begin{array}{llllll}\text { International Journal, } & \text { Vol. } 25 & \text { No. } & 4, & \text { pp. } & \text { 762-769. }\end{array}$ https://doi.org/10.1108/13639510210450677 
Williamson K. Research Methods for Students, Academics and Professionals, Information Management and Systems, A volume in Topics in Australasian Library and Information Studies Book Second Edition 2002, Chapter 12 - The Delphi method https://doi.org/10.1016/B978-1-876938-42-0.50020-4; pp 209-220 